УДК 621.391

\title{
АЛГОРИТМЫ 3D-РАДИОВИДЕНИЯ В БОРТОВОЙ ДОПЛЕРОВСКОЙ РЛС*
}

\author{
КЛОЧКО В. К.
}

\author{
Рязанский государственный радиотехнический университет,
} Россия, Рязань, 390005, ул. Гагарина, д. 59/1

\begin{abstract}
Аннотация. Предложены алгоритмы оценивания координат элементов земной поверхности в системе 3D-радиовидения на базе бортовой доплеровской РЛС маловысотного полета. Показана применимость алгоритмов методом компьютерного моделирования
\end{abstract}

Ключевые слова: радиолокация; 3D-изображение; доплеровская фильтрация; оценки координат; маловысотный полет

\section{ВВЕДЕНИЕ}

В конце 90-х годов возникла концепция информационного обеспечения маловысотного полета (МВП) на базе бортовой РЛС [1], направленная на повышение безопасности такого полета в условиях сложного рельефа местности. Возможность увидеть препятствия по курсу полета достигалась, в основном, формированием узкой диаграммы направленности антенны (ДНА) по азимуту и ее сканированием в режиме реального луча. Однако увидеть детальное изображение препятствий в таком режиме невозможно. Появился ряд работ, посвященных сверхразрешению на основе методов восстановления изображений при сканировании ДНА, например [2]. Но эффект повышения разрешающей способности по угловым координатам за счет восстановления оказался небольшим - не более чем в 3 раза.

Радиовидение на базе бортовой доплеровской РЛС в режиме доплеровского «обужения луча» (ДОЛ) [3] позволяет повысить угловое разрешение в десятки раз и сформировать детальное двумерное амплитудное радиолокационное изображение (2D-РЛИ) местности в координатах дальность-доплеровская частота. В режиме ДОЛ возможно также сформировать трехмерное РЛИ (3D-РЛИ) и карту высот [4], однако погрешность измерения высоты соизмерима с линейной шириной ДНА по углу места.

Известно несколько подходов к формированию матрицы высот рельефа местности [3], которые возможно применить в доплеровской РЛС. Это использование высокоточной интерферометрической системы, формирование матрицы высот за счет сканирования по углу места, измерение высоты с помощью радиолокационной тени. Анализ этих подходов на алгоритмическом уровне показывает необходимость применения специальных процедур для пространственного совмещения двух (интер-

* Работа выполнена при поддержке гранта РШ-7116.2016.8.

DOI: $10.20535 / \mathrm{S} 0021347016080021$

(С) Клочко В. К., 2016 